\title{
Aromatase Inhibitor, Flax seed and Sage Effects on Adult Rats Fertility and Sexual Behavior
}

\author{
Heba Mohammed Jasem ${ }^{1 *}$; Fadwa Khalid Tawfeek ${ }^{2}$ \\ ${ }^{1,2}$ Department of physiology, biochemistry and pharmacology, Veterinary medicine, University of Mosul, \\ Mosul, Iraq \\ Email: ${ }^{1 *}$ hebaasem2010@gmail.com, ${ }^{2}$ fadwaameen@yahoo.com
}

(Received April 29, 2019; Accepted September 23, 2019; Available online June 01, 2020)

DOI: 10.33899/edusj.2020.165306, @ 2020, College of Education for Pure Science, University of Mosul.

This is an open access article under the CC BY 4.0 license (http://creativecommons.org/licenses/by/4.0/).

\begin{abstract}
The current study was designed to detect estrogen role in adult male rats by giving aromatase inhibitor ( ltrozole $1 \mathrm{mg} / \mathrm{Kg}$. B. W) for 60 days orally to inhibit aromatase enzyme activity and to study the effect of giving source of estrogen flax seeds $(25 \mathrm{~g} / 100 \mathrm{~g}$ diet $)$ and aqueous extract sage $(1000 \mathrm{mg} / \mathrm{Kg}$. B.W.) orally. The study showed that adult male rats treated with ltrozole resulted in a significant decrease in the weight of testes, prostate, percentage of live sperms , number of sperms , number of mounting, intromission, ejaculation and in the time period from mixing with females to the first mounting, intromission and ejaculation, the time period between mount and another, intromission and another, ejaculation and another, and significant increase in the percentages of dead as well as abnormal sperms. Flax seeds treatment significantly reduced percentage of live sperms, number of sperms, number of mounting, intromission, and ejaculation, and significantly increased percentage of dead sperms compared with control group. Sage extract treatment caused a significant decrease in number of sperms, number of mounting, intromission and ejaculation, as well as a significant increase in the time period from mixing of female to the first mounting, first intromission and first ejaculation compared with control. The results showed that administration of sage extract with letrozole showed a significant increase in testis weight, percentages of live sperms and number of sperms, and asignificant decrease in dead and abnormal sperms compared with the letrozole group. Administration of flax seed with letrozole did not significantly change weight of the testis , prostate, percentage of live, dead, abnormal sperm and number of sperm compared with letrozole group. Administration of Flax seed and sage extracts to male rats treated with letrozole did not significantly change all the done tests of sex behavior. The study concluded that estrogen has an important role in the function of male reproductive system, which is shown through the negative effects of the aromatase inhibitor on the weights of the testis, prostate, live and dead and abnormal sperm, and sexual behavior. Sage extract, but not flax seed, has benefit effects on the defect induced by aromatase inhibitor letrozole both flax seed and sage do not produce positive effects on sexual behavior .
\end{abstract}

keywords: Aromatase, Ltrozole, Flax seed, Sage, Estrogen, Male reproductive system. 


\title{
تاثيرات مثبط الاروماتيز وبذور الكتان والميرامية في الخصوبة والسلوك الجنسي للجرذان البالغة
}

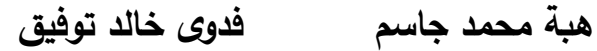 \\ فرع الفسلجة والكيمياء الحياتية والأدوية، كلية الطب البيطري، جامعة الموصل، الموصل, العرلق
}

صمدت الدراسة الحالية للكثف عن دور (الأستروجين) في ذكور الجرذان البالغة من خلال إعطاء مثبط الأروماتيز (اللتروزول

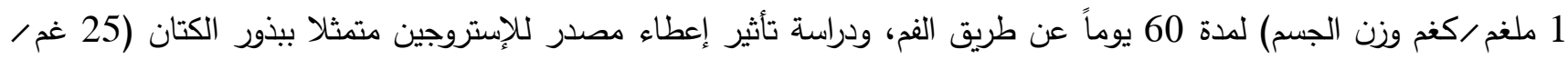
100 غم عليقة) ومستخلص الميرامية المائي (1000 ملغم/كغم وزن الجسم ) عن طريق الفم ـ أحدث اللتروزول انخفاضاً معنوياً في وزن الخصى والبروستات والنسب المئوية للنطف الحية وعدد النطف وعدد مرات الصعود والولوج والقذف، وفي الفترة الزمنية من بداية

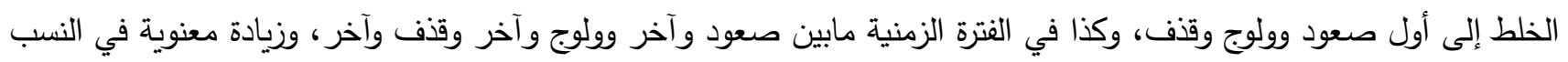

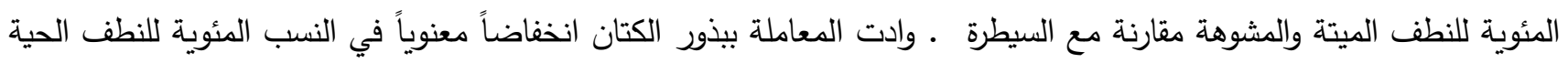
وعدد النطف وفي عدد مرات الصعود والولوج والقذف، وزيادة معنوية في النسب المئوية للنطف الميتة مقارنة مع السيطرة ـ وادت المعاملة بمستخلص الميرامية انخفاضاً معنوياً في عدد النطف وعدد مرات الصعود والولوج والقذف، وزيادة معنوية في الفترة الزمنية

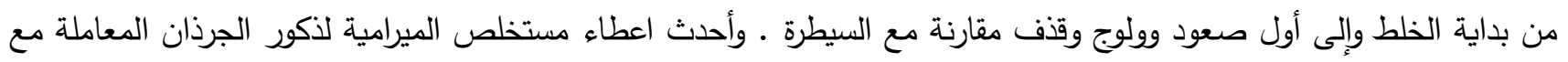

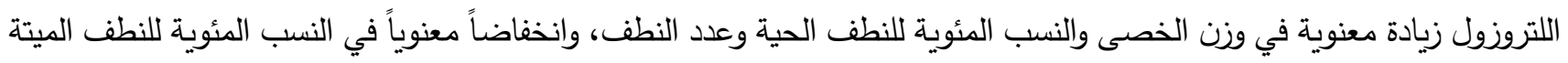
والمشوهة مقارنة مع المجموعة المعاملة باللتروزول وحده ـ ولم تحدث معاملة ذكور الجرذان المعاملة باللتروزول مع بذور الكتان تغييراً

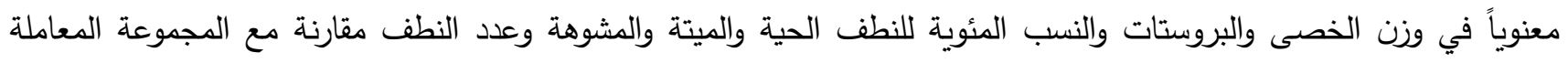

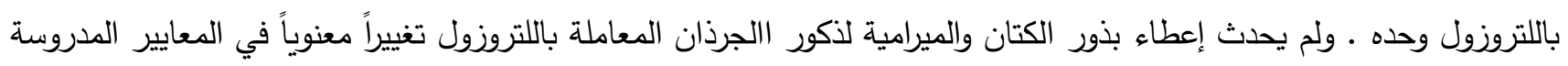
للسلوك الجنسي، ولم تظهر حيوانات هذه المجاميع أي سلوك جنسي • نستنتج من هذه الدراسة أن للاستروجين دوراً مهماً في وظيفة

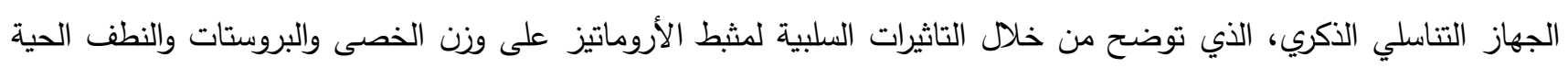
والميتة والمشوهة والسلوك الجنسي لذكور الجرذان، و تمتلك الميرامية وليس بذور الكتان بعض التأثير المحسن للخلل المحدث بوساطة

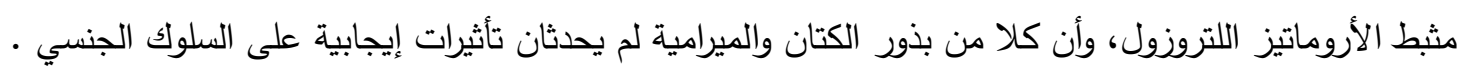
الكلمات الدالة: اروماتيز، لتروزول، بذور الكتان، ميرامية، استروجين، الجهاز التكاثري الذكري .

\section{Introduction}

Estrogen has important effect in male reproductive function ; estradiol in men is important for modifying libido, erectile function and spermatogenesis (1). Estrogen receptors as well as aromatase , the enzyme that synthesizes estrogen from testosterone are present in brain, penis, testis which are importants for sexual function (2). Estrogen exerts protective effects in different cell types and increases glutathione levels in different cells (3). Male fertility is controled by estrogens , particularly in rodents; when estrogen receptor alpha and/ or aromatase enzyme lose their function this leads to infertility in mice (4). Estrogen deficiencies promote apoptosis of round spermatids before differentiating into elongated spermatids (5). Daily injections of $100 \mu \mathrm{g}$ estradiol benzoate improve sexual behavior in castrated male rats (5). The identification of estrogen roles in males can be 
determined by suppression action of aromatase enzyme in normal animals by administration of aromatase inhibitors (6). Aromatase inhibitors are class of drugs used to reduce testosterone conversion to estrogen (7). Leydig cells hyperplasia/hypertrophy and stop of spermatogenesis are produced by administration of letrozole to adult male dogs for 3 months (8). Administration of aromatase inhibitor letrozole ( $0.5 \mathrm{mg} / \mathrm{Kg}$. B.W.) to male wester rats reduced fertility, decreased aggression and strongly modified mating behavior by decreasing sexual desire(9). Phytoestrogens represent a group of natural products that represent polyphenolic and non-steroid compounds that have a similar structure and biological activity as estrogens (10). Flax seed is high in $\alpha$ - linolenic acid and its a richest source of lignin, which resembles endogenous estrogens (11). Linolenic acid, an indirect precursor of prostaglandins, prostaglandin in semen promote sperm motility and the penetration of cervical mucus by sperm (12). Chronic admenistration of $25 \%$ flax seed meals from gestation to 250 days of age by young adult male wistar rats caused high serum concentration of estrogen (13). Salvia plant (Salvia Officinalis) also called sage contains polyphenol compounds, comprising phenolic acids and flavonoids (phytoestrogens ); this plant also rich in essential oils with large array of terpenoids (14). Diabetic rats treated with sage showed significant elevation in sperm count, sperm viability, sperm motility and morphology, sage caused significant reduction in blood glucose levels; these effects may be attributed to their antioxidant activites (15). Other studies have shown that normal function of leydig cells can be maintained by the antioxidants within salvia extracts (16). Moreover, the presence of vitamins $\mathrm{C}$ and $\mathrm{E}$ in sage also has a useful effect in the treatment of male infertility ; so that the use of Salvia Officinalis might increase fertility in male mice (17). Growth of testes , proliferation, maturation and differentiation of sperms can be enhanced and stimulated by administration of Salvia extract (18).

\section{Materials and Methods:}

Eight four adult albino male rats were obtained from the animal house of the veterinary medical college-university of Mosul at (90-100) days of age. They were housed in polypropylene cages $(20 \times 25 \times 20)$ under conditions of temperature $\left(18 \pm 2{ }^{\circ} \mathrm{C}\right)$ and lighting $(10$ hours light $/ 14$ hours dark ). The rats were fed on diet without soybean and tap water ad libitum . The experiment consists of 6 groups; each group contains 7 animals; the treatment of these animals continued for 60 days . the control group received distilled water orally.the second group received letrozole( $1 \mathrm{mg} / \mathrm{Kg}$. B.W) orally(19) the third group received flax seed $(25 \mathrm{~g} / 100 \mathrm{~g} \mathrm{diet})(20)$.the fourth group received aqueous extract sage $(1000 \mathrm{mg} / \mathrm{Kg}$. B.W ) (21).the fifth group received letrozole ( $1 \mathrm{mg} / \mathrm{Kg}$. B.W ) orally and flax seed $(25 \mathrm{~g} / 100 \mathrm{~g}$ diet $)$ with diet the sixth group received letrozole $(1 \mathrm{mg} / \mathrm{Kg}$. B.W) and aqueous extract sage $(1000 \mathrm{mg} / \mathrm{Kg} \mathrm{B.W})$ orally . At the end of the treatment, animals are divided into two groups (each group includes 42 rats ) weights of animals in the first group were recorded. Animals were sacrificed. The abdomen was incised and both testes, epididymus, seminal vesicles and prostate were separated and weighted . Sperm counted by using hemocytometric method (22). The percentage of live, dead and abnormal sperms were counted in smear from epididymal tail by using eosin - nigrosin stain (23). The males in the second group placed in plastic cages, with sexually accepted normal females (at estrus ), to study the sexual behavior (one male with one female ) by using (24) methods. sexual behavior studied by recording number of mount, intromission and ejaculation, the time interval from mixing male and female to first mount, intromission and ejaculation, the period between one mount and another, one intromission and another, as well as one ejaculation and another. 


\section{Results:}

As shown in table (1), treatment with letrozole caused significant reduction $(p<0.05)$ in the weight of testes, prostate compared with control group. Administration of flax seed and sage extract produce no changes in studied parameters. Administration of flax seed to male rats treated with letrozole produced no significant changes in all studied parameters . Administration of sage to male rats treated with letrozole caused significant increase $(\mathrm{p} \leq 0.05)$ in the testes weight and no significant changes in prostate weight compared with letrozole group .Table (2) showed that Administration of letrozole caused significant reduction $(\mathrm{p} \leq 0.05)$ in the percentage of live sperms and total number of sperms as well as significant elevation in the percentage of dead and abnormal sperms compared with control group. Administration of flax seed produced significant decrease in the percentage of live sperms, number of sperms and also significant increase in the percentage of dead sperms. Treatment of adult male rat with sage caused significant decrease in the total number of sperms compared with control group . Administration of flax seed to adult male rats treated with letrozole caused no significant changes in all studied parameters. Administration of sage extract to male rats treated with letrozole produced significant elevation in the live sperm percentage and number of sperm and also a significant decrease in the dead and abnormal sperm percentage compared with letrozole group. Table (3) showed that treatment of adult male rat with letrozole caused significant decrease in the number of mount , intromission, ejaculation compared with control group . Treatment with flax seed and sage extract caused significant decrease in the number of mount, intromission, ejaculation compared with control group. Administration of sage extract and flax seed to adult male rate treated with letrozole did not caused significant changes in the number of mount, intromission, ejaculation compared with letrozole group only. Table (4) showed that treatment of adult male rate with letrozole caused significant decrease in time period from mixing with female to the first mount, first intromission and first ejaculation compared with control group . treatment of adult male rat with sage extract caused significant increase in time period from mixing with female to the first mount, first intromission and first ejaculation compared with control group. Administration of sage extract and flax seed to adult male rat treated with letrozole did not cause significant changes in the time period from mixing with female to the first mount ,first intromission and first ejaculation compared with letrozole group. Table (5) showed that administration of letrozole to adult male rats caused significant decrease in the time interval between one mount and another, intromission and another ,ejaculation and another compared with control group. Administration of flax seed and sage did not cause significant changes in the time interval between one mount and another, intromission and another, ejaculation and another compared with control group. Administration of sage extract and flaxseed to adult male rat treated with letrozole caused no significant changes in the time interval between one mount and another, intromission and another ,ejaculation and another compared with letrozole group only. 
Tabel (1):Effect of letrozole ,flax seed, aqueous extract sage on weight of body, testis, head, body ,tail of epydidmas, prostate and seminal vesicle of adult male rat

\begin{tabular}{|c|c|c|c|c|c|c|c|}
\hline $\begin{array}{l}\text { Treatment } \\
\text { group }\end{array}$ & $\begin{array}{c}* \\
\text { Body } \\
\text { weight } \\
(\mathrm{g})\end{array}$ & $\begin{array}{c}\text { Testis } \\
\text { weight } \\
\text { (mg/100g } \\
\text { body } \\
\text { weight) }\end{array}$ & $\begin{array}{c}\text { Epididymal } \\
\text { head weight } \\
(\mathrm{mg} / 100 \mathrm{~g} \\
\text { body weight })\end{array}$ & $\begin{array}{c}\text { Epididymal } \\
\text { body weight } \\
(\mathrm{mg} / 100 \mathrm{~g} \\
\text { body weight })\end{array}$ & $\begin{array}{c}\text { Epididymal } \\
\text { tail weight } \\
\text { (mg/100g } \\
\text { body weight) }\end{array}$ & $\begin{array}{c}\text { Prostate } \\
\text { weight } \\
\text { (mg/100g body } \\
\text { weight) }\end{array}$ & $\begin{array}{c}\text { Seminal } \\
\text { vesicle } \\
\text { weight } \\
\text { (mg/100g } \\
\text { body } \\
\text { weight) }\end{array}$ \\
\hline Control & $\begin{array}{c}305.54 \\
\pm \\
18.89 \\
\mathrm{a}\end{array}$ & $\begin{array}{c}454.21 \\
\pm \\
75.91 \\
\text { a b }\end{array}$ & $\begin{array}{c}77.86 \\
\pm \\
11.28 \\
\mathrm{a}\end{array}$ & $\begin{array}{c}13.00 \\
\pm \\
4.47 \\
\mathrm{a}\end{array}$ & $\begin{array}{c}92.71 \\
\pm \\
13.86 \\
\mathrm{a}\end{array}$ & $\begin{array}{c}319.57 \\
\pm \\
96.40 \\
\text { A }\end{array}$ & $\begin{array}{c}456.43 \\
\pm \\
59.70 \\
\text { a b }\end{array}$ \\
\hline $\begin{array}{c}\text { Letrozole } \\
\text { 1mg/Kg. } \\
\text { B.W }\end{array}$ & $\begin{array}{c}294.29 \\
\pm \\
61.18 \\
\mathrm{a}\end{array}$ & $\begin{array}{c}272.29 \\
\pm \\
63.73 \\
d\end{array}$ & $\begin{array}{c}86.643 \\
\pm \\
7.54 \\
\mathrm{a}\end{array}$ & $\begin{array}{c}11.43 \\
\pm \\
1.62 \\
\mathrm{a}\end{array}$ & $\begin{array}{c}84.57 \\
\pm \\
19.17 \\
\mathrm{a}\end{array}$ & $\begin{array}{c}210.29 \\
\pm \\
49.17 \\
\text { b c }\end{array}$ & $\begin{array}{c}347.14 \\
\pm \\
62.85 \\
\text { b c }\end{array}$ \\
\hline $\begin{array}{c}\text { Flax seed } \\
25 \mathrm{gm} / 100 \mathrm{~g} \\
\text { diet }\end{array}$ & $\begin{array}{c}310.14 \\
\pm \\
49.85 \\
\text { a }\end{array}$ & $\begin{array}{c}464.00 \\
\pm \\
68.8 \\
\mathrm{a}\end{array}$ & $\begin{array}{c}83.86 \\
\pm \\
10.81 \\
\mathrm{a}\end{array}$ & $\begin{array}{c}12.86 \\
\pm \\
4.10 \\
\mathrm{a}\end{array}$ & $\begin{array}{c}94.57 \\
\pm \\
13.60 \\
\mathrm{a}\end{array}$ & $\begin{array}{c}332.29 \\
\pm \\
62.34 \\
\text { A }\end{array}$ & $\begin{array}{c}470.43 \\
\pm \\
96.42 \\
\mathrm{a}\end{array}$ \\
\hline $\begin{array}{c}\text { Sage extract } \\
1000 \mathrm{mg} / \\
\text { Kg. B.W }\end{array}$ & $\begin{array}{c}327.57 \\
\pm \\
67.09 \\
\mathrm{a}\end{array}$ & $\begin{array}{c}472.86 \\
\pm \\
99.58 \\
\mathrm{a}\end{array}$ & $\begin{array}{c}81.71 \\
\pm \\
14.67 \\
\mathrm{a}\end{array}$ & $\begin{array}{c}15.86 \\
\pm \\
4.84 \\
\mathrm{a}\end{array}$ & $\begin{array}{c}83.70 \\
\pm \\
32.10 \\
\mathrm{a}\end{array}$ & $\begin{array}{c}291.43 \\
\pm \\
49.60 \\
\text { A }\end{array}$ & $\begin{array}{c}465.00 \\
\pm \\
97.58 \\
\mathrm{a}\end{array}$ \\
\hline $\begin{array}{c}\text { Letrozole } \\
+ \\
\text { Flax seed }\end{array}$ & $\begin{array}{c}321.57 \\
\pm \\
37.62 \\
\mathrm{a}\end{array}$ & $\begin{array}{c}370.29 \\
\pm \\
57.15 \\
\text { b c }\end{array}$ & $\begin{array}{c}86.64 \\
\pm \\
9.45 \\
\mathrm{a}\end{array}$ & $\begin{array}{c}13.86 \\
\pm \\
4.98 \\
\mathrm{a}\end{array}$ & $\begin{array}{c}88.14 \\
\pm \\
12.95 \\
\mathrm{a}\end{array}$ & $\begin{array}{c}282.43 \\
\pm \\
81.44 \\
\text { a b }\end{array}$ & $\begin{array}{c}394.71 \\
\pm \\
109.40 \\
\text { a b c }\end{array}$ \\
\hline $\begin{array}{c}\text { letrozole+ } \\
\text { Sage extract }\end{array}$ & $\begin{array}{c}304.43 \\
\pm \\
93.52 \\
\mathrm{a}\end{array}$ & $\begin{array}{c}332.14 \\
\pm \\
103.74 \\
\text { c d }\end{array}$ & $\begin{array}{c}75.14 \\
\pm \\
21.64 \\
a\end{array}$ & $\begin{array}{c}14.00 \\
\pm \\
4.58 \\
\mathrm{a}\end{array}$ & $\begin{array}{c}73.14 \\
\pm \\
14.67 \\
\mathrm{a}\end{array}$ & $\begin{array}{c}152.71 \\
\pm \\
59.58 \\
C\end{array}$ & $\begin{array}{c}333.43 \\
\pm \\
132.92 \\
\text { c }\end{array}$ \\
\hline
\end{tabular}

Values are mean $\pm \mathrm{SD}$. For 7 replicate $(\mathrm{n}=7$ rats $/$ group $) . *$

The different letters vertically are significantly different at $(\mathrm{p} \leq 0.05)$. 
Journal of Education and Science (ISSN 1812-125X), Vol: 29, No: 2, 2020 (174-185)

Tabel (2):Effect of letrozole ,flax seed, aqueous extract sage on percentage of live , dead abnormal sperms and number of sperms of adult male rat

\begin{tabular}{|c|c|c|c|c|}
\hline $\begin{array}{l}\text { Treatment } \\
\text { groups }\end{array}$ & $\begin{array}{c}\text { Live sperm* } \\
(\%)\end{array}$ & $\begin{array}{c}\text { Dead sperm } \\
(\%)\end{array}$ & $\begin{array}{c}\text { Abnormal } \\
\text { sperm } \\
(\%)\end{array}$ & $\begin{array}{l}\text { Sperm count } \\
\left(\text { cell } / \mathbf{m m}^{3}\right)\end{array}$ \\
\hline Control & $\begin{array}{c}73.15 \\
\pm \\
3.12 \\
\mathrm{a}\end{array}$ & $\begin{array}{c}26.85 \\
\pm \\
3.52 \\
c\end{array}$ & $\begin{array}{c}9.67 \\
\pm \\
2.90 \\
b\end{array}$ & $\begin{array}{c}1084286.7 \\
\pm \\
370533.4 \\
\mathrm{a}\end{array}$ \\
\hline $\begin{array}{c}\text { Letrozole } \\
\text { 1 mg/Kg. B.W }\end{array}$ & $\begin{array}{c}34.00 \\
\pm \\
8.05 \\
c\end{array}$ & $\begin{array}{c}66.00 \\
\pm \\
8.23 \\
\mathrm{a}\end{array}$ & $\begin{array}{c}20.81 \\
\pm \\
5.74 \\
\mathrm{a}\end{array}$ & $\begin{array}{c}311429 \\
\pm \\
208041 \\
c\end{array}$ \\
\hline $\begin{array}{c}\text { Flax seed } \\
25 \mathrm{gm} / 100 \mathrm{gm} \\
\text { dait }\end{array}$ & $\begin{array}{c}41.00 \\
\pm \\
6.74 \\
\text { b c }\end{array}$ & $\begin{array}{c}59.00 \\
\pm \\
6.83 \\
\mathrm{a}\end{array}$ & $\begin{array}{c}14.61 \\
\pm \\
4.94 \\
\text { a b }\end{array}$ & $\begin{array}{c}291429 \\
\pm \\
167673 \\
c\end{array}$ \\
\hline $\begin{array}{l}\text { Sage extract } \\
1000 \mathrm{mg} / \mathrm{Kg} . \\
\text { B.W }\end{array}$ & $\begin{array}{c}66.5 \\
\pm \\
7.41 \\
\mathrm{a}\end{array}$ & $\begin{array}{c}33.50 \\
\pm \\
7.53 \\
c\end{array}$ & $\begin{array}{c}8.07 \\
\pm \\
3.95 \\
\mathrm{~b}\end{array}$ & $\begin{array}{c}692857 \\
\pm \\
151516 \\
b\end{array}$ \\
\hline $\begin{array}{c}\text { Letrozole } \\
+ \\
\text { Flax seed }\end{array}$ & $\begin{array}{c}50.13 \\
\pm \\
13.47 \\
\mathrm{~b} \\
\end{array}$ & $\begin{array}{c}49.87 \\
\pm \\
13.47 \\
\mathrm{~b} \\
\end{array}$ & $\begin{array}{c}11.35 \\
\pm \\
4.48 \\
\mathrm{~b} \\
\end{array}$ & $\begin{array}{c}580000 \\
\pm \\
202731 \\
\text { b } \\
\end{array}$ \\
\hline $\begin{array}{c}\text { Letrozole } \\
+ \\
\text { Sage extract }\end{array}$ & $\begin{array}{c}31.74 \\
\pm \\
7.90 \\
c\end{array}$ & $\begin{array}{c}68.26 \\
\pm \\
7.89 \\
\mathrm{a}\end{array}$ & $\begin{array}{c}20.94 \\
\pm \\
9.73 \\
\mathrm{a}\end{array}$ & $\begin{array}{c}181429 \\
\pm \\
96164 \\
\text { c }\end{array}$ \\
\hline
\end{tabular}

* Values are mean \pm SD. For 7 replicate $(n=7$ rats $/$ group $)$.

The different letters vertically are significantly different at $(\mathrm{p} \leq 0.05)$. 
Tabel (3):Effect of letrozole ,flax seed, aqueous extract sage on number of mount, intromission and ejaculation of adult male rat

\begin{tabular}{|c|c|c|c|}
\hline Treatment groups & No. of mounts * & No. of intromission & No. of ejaculation \\
\hline \multirow{4}{*}{ Control } & 13.57 & 4.71 & 7.14 \\
\hline & \pm & \pm & \pm \\
\hline & 5.06 & 1.70 & 3.34 \\
\hline & $\mathrm{a}$ & $\mathrm{a}$ & $\mathrm{a}$ \\
\hline \multirow{4}{*}{$\begin{array}{c}\text { Letrozole } \\
\text { 1 mg/Kg. B.W }\end{array}$} & 0.00 & 0.00 & 0.00 \\
\hline & \pm & \pm & \pm \\
\hline & 0.00 & 0.00 & 0.00 \\
\hline & $\mathrm{c}$ & $c$ & $\mathrm{c}$ \\
\hline \multirow{4}{*}{$\begin{array}{c}\text { Flax seed } \\
25 \mathrm{gm} / 100 \text { gm diet }\end{array}$} & 7.71 & 2.14 & 4.17 \\
\hline & \pm & \pm & \pm \\
\hline & 2.93 & 1.07 & 1.50 \\
\hline & $\mathrm{b}$ & $\mathrm{b}$ & $\mathrm{b}$ \\
\hline \multirow{4}{*}{$\begin{array}{c}\text { Sage extract } \\
1000 \mathrm{mg} / \mathrm{Kg} . \mathrm{B} . \mathrm{W}\end{array}$} & 6.29 & 1.57 & 4.14 \\
\hline & \pm & \pm & \pm \\
\hline & 1.50 & 0.53 & 0.90 \\
\hline & $\mathrm{b}$ & $\mathrm{b}$ & $\mathrm{b}$ \\
\hline \multirow{4}{*}{$\begin{array}{c}\text { Letrozole } \\
+ \\
\text { Flax seed }\end{array}$} & 0.00 & 0.00 & 0.00 \\
\hline & \pm & \pm & \pm \\
\hline & 0.00 & 0.00 & 0.00 \\
\hline & $\mathrm{c}$ & $\mathrm{c}$ & $\mathrm{c}$ \\
\hline \multirow{4}{*}{$\begin{array}{c}\text { Letrozole } \\
+ \\
\text { Sage extract }\end{array}$} & 0.00 & 0.00 & 0.00 \\
\hline & \pm & \pm & \pm \\
\hline & 0.00 & 0.00 & 0.00 \\
\hline & & $\mathrm{c}$ & $\mathrm{c}$ \\
\hline
\end{tabular}

* Values are mean \pm SD. For 7 replicate $(n=7$ rats $/$ group $)$.

The different letters vertically are significantly different at $(\mathrm{p} \leq 0.05)$. 
Tabel (4):Effect of letrozole, flaxseed, aqueous extract sage on period time from mixing of female to first mount, intromission and ejaculation of adult male rat

\begin{tabular}{|c|c|c|c|}
\hline Treatment groups & $\begin{array}{c}\text { Time from mixing } \\
\text { to first mount * } \\
\text { (sec.) }\end{array}$ & $\begin{array}{l}\text { Time from mixing } \\
\text { to first } \\
\text { intromission (sec.) }\end{array}$ & $\begin{array}{l}\text { Time from mixing } \\
\text { to first ejaculation } \\
\text { (sec.) }\end{array}$ \\
\hline Control & $\begin{array}{c}270.57 \\
\pm \\
135.19 \\
\text { B }\end{array}$ & $\begin{array}{c}439.00 \\
\pm \\
237.67 \\
\text { b }\end{array}$ & $\begin{array}{c}398.71 \\
\pm \\
237.06 \\
\text { b }\end{array}$ \\
\hline $\begin{array}{c}\text { Letrozole } \\
1 \mathrm{mg} / \mathrm{Kg} . \mathrm{B} . \mathrm{W}\end{array}$ & $\begin{array}{c}0.00 \\
\pm \\
0.00 \\
\mathrm{C}\end{array}$ & $\begin{array}{c}0.00 \\
\pm \\
0.00 \\
c\end{array}$ & $\begin{array}{c}0.00 \\
\pm \\
0.00 \\
c\end{array}$ \\
\hline $\begin{array}{c}\text { Flax seed } \\
25 \mathrm{gm} / 100 \mathrm{gm} \text { diet }\end{array}$ & $\begin{array}{c}396.57 \\
\pm \\
254.88 \\
\text { B }\end{array}$ & $\begin{array}{c}477.00 \\
\pm \\
204.58 \\
\text { a b }\end{array}$ & $\begin{array}{c}482.29 \\
\pm \\
182.69 \\
\mathrm{a} \mathrm{b}\end{array}$ \\
\hline $\begin{array}{c}\text { Sage extract } \\
1000 \mathrm{mg} / \mathrm{Kg} . \text { B.W }\end{array}$ & $\begin{array}{c}552.57 \\
\pm \\
112.69 \\
\text { A }\end{array}$ & $\begin{array}{c}602.86 \\
\pm \\
111.92 \\
\mathrm{a}\end{array}$ & $\begin{array}{c}601.14 \\
\pm \\
87.50 \\
\mathrm{a}\end{array}$ \\
\hline $\begin{array}{c}\text { Letrozole } \\
+ \\
\text { Flax seed }\end{array}$ & $\begin{array}{c}0.00 \\
\pm \\
0.00 \\
\mathrm{C}\end{array}$ & $\begin{array}{c}0.00 \\
\pm \\
0.00 \\
c\end{array}$ & $\begin{array}{c}0.00 \\
\pm \\
0.00 \\
c\end{array}$ \\
\hline $\begin{array}{c}\text { Letrozole } \\
+ \\
\text { Sage extract }\end{array}$ & $\begin{array}{c}0.00 \\
\pm \\
0.00 \\
\mathrm{C}\end{array}$ & $\begin{array}{c}0.00 \\
\pm \\
0.00 \\
c\end{array}$ & $\begin{array}{c}0.00 \\
\pm \\
0.00 \\
c\end{array}$ \\
\hline
\end{tabular}

* Values are mean \pm SD. For 7 replicate $(n=7$ rats $/$ group $)$.

The different letters vertically are significantly different at $(\mathrm{p} \leq 0.05)$. 
Tabel (5):Effect of letrozole,flax seed, aqueous extract sage on time period between mount and another, intromission and another and ejaculation and another of adult male rat

\begin{tabular}{|c|c|c|c|}
\hline Treatment groups & $\begin{array}{c}\text { Time between } \\
\text { mount and } \\
\text { another (sec.) } *\end{array}$ & $\begin{array}{c}\text { Time between } \\
\text { intrumission and } \\
\text { another (sec.) }\end{array}$ & $\begin{array}{l}\text { Time between } \\
\text { ejaculation and } \\
\text { another (sec.) }\end{array}$ \\
\hline \multirow{4}{*}{ Control } & 34.47 & 74.38 & 45.67 \\
\hline & \pm & \pm & \pm \\
\hline & 30.47 & 67.31 & 33.61 \\
\hline & $\mathrm{a}$ & $\mathrm{a}$ & $\mathrm{a}$ \\
\hline \multirow{4}{*}{$\begin{array}{l}\text { Letrozole } \\
1 \mathrm{mg} / \text { Kg.B.W }\end{array}$} & 0.00 & 0.00 & 0.00 \\
\hline & \pm & \pm & \pm \\
\hline & 0.00 & 0.00 & 0.00 \\
\hline & $\mathrm{b}$ & $\mathrm{b}$ & $\mathrm{b}$ \\
\hline \multirow{4}{*}{$\begin{array}{c}\text { Flax seed } \\
\text { 25gm/100gm diet }\end{array}$} & 40.00 & 123.37 & 63.89 \\
\hline & \pm & \pm & \pm \\
\hline & 30.07 & 102.54 & 35.51 \\
\hline & $\mathrm{a}$ & $\mathrm{a}$ & $\mathrm{a}$ \\
\hline \multirow{4}{*}{$\begin{array}{c}\text { Sage extract } \\
1000 \mathrm{mg} / \mathrm{Kg} . \mathrm{B} . \mathrm{W}\end{array}$} & 36.41 & 122.20 & 55.77 \\
\hline & \pm & \pm & \pm \\
\hline & 24.30 & 89.67 & 33.66 \\
\hline & $\mathrm{a}$ & $\mathrm{a}$ & $\mathrm{a}$ \\
\hline \multirow{4}{*}{$\begin{array}{c}\text { Letrozole } \\
+ \\
\text { Sage }\end{array}$} & 0.00 & 0.00 & 0.00 \\
\hline & \pm & \pm & \pm \\
\hline & 0.00 & 0.00 & 0.00 \\
\hline & $\mathrm{b}$ & $\mathrm{b}$ & $\mathrm{b}$ \\
\hline \multirow{4}{*}{$\begin{array}{c}\text { Letrozole } \\
+ \\
\text { Flax seed }\end{array}$} & 0.00 & 0.00 & 0.00 \\
\hline & \pm & \pm & \pm \\
\hline & 0.00 & 0.00 & 0.00 \\
\hline & $\mathrm{b}$ & $\mathrm{b}$ & $\mathrm{b}$ \\
\hline
\end{tabular}

$*$ Values are mean \pm SD. For 7 replicate $(n=7$ rats $/$ group $)$.

The different letters vertically are significantly different at $(\mathrm{p} \leq 0.05)$.

\section{Discussion:}

The results of letrozole administration in the present study are in agreement with the previous studies (6) in which the treatment with anastrozole to adult male rats in drinking water for 9 weeks caused significant decrease in prostatic weight, decrease in the number of lydige cells and also caused failure of mating. Another study demonstrated that administration of aromatase inhibitor fulvestrant to mice reduced sperm concentration in the tail of epididymis , sperm motility and fertility (25). Hypothalamus secret gonadotropen-releasing hormone which stimulates pituitary gland to release follicl stimulating hormone( FSH) and luteinizing hormone ( $\mathrm{LH}$ ), FSH enter the testis and stimulate sertoli cells facilitating spermatogenesis, LH stimulate interstitial cells in testis (leydig cells)to release testosterone ; the later acts on hypothalamus and anterior pituitary to inhibit the release of FSH and LH by( negative feed back) aromatase inhibitor that completely inhibits testosterone effect on 
gonadotropins secretion (26). administration of aromatase inhibitor caused hormonal disturbance and defect in hypothalamic-pituitary-testis axis which may be reflected by the total sperms count and percentage of live sperms reduction and dead as well as abnormal sperms percentage elevation in the present study . Production of endocrine defect by estrogenic or antiestrogenic compounds reduced the sperms number and increased disturbances of male reproductive system (27). Blockage Induction of estrogen action in the rodents, either by using of aromatase inhibitor or by disruption of estrogen receptors, caused general fertilty disruption, There is an evidence that this causes impairment in the testicular function, atrophy of interstitial cells , disruption of seminiferous epithelial and decrease in sperms count and sexual activity (28). This may be the cause of negative effect of letrozole in the present study. Estrogen play important role in sexual behavior treatment with estrogen caused longer latencies and more mounts and intromissions prior to ejaculation in male rats (5). Estrogen synthesized in tissue like breast and preoptic area in the brain and the sight at which testosterone stimulates male sex behavior specially mounting estrogen produced at this area promote mounting ; this effect is inhibited by using aromatase inhibitor in male monkeys , rats , quail $(29 ; 30 ; 31)$. Flax seed rich with lignin, which is phytoestrogen and may act as competitive inhibitor to aromatase enzyme; it competed with endogenous estradiol which is much potent and act as inhibitor for aromatase enzyme (32).In the present study flax seed did not correct the negative effect induced by letrozole ; this may be caused by its antiestrogenic effects, or may be possibly due to the time duration or the dose of the study. Administration of flax seed to rats at different stages of development caused different significant changes depending on their dose; $10 \%$ flax seed with diet caused (estrogenic effects) earlier puberty onset, increases in the levels of testosterone and estradiol in the serum , whereas administration of flax seed $5 \%$ with diet delayed puberty onset reduce prostate weights (anti estrogenic effects) (33). Administration with flax seed $25 \%$ with diet for long time from gestation to 250 days of age by young adult male wistar rats caused high serum concentration of estrogen (13). The effects of flax seed in the present study may result from its dose or my result from the inhibitory effects of flax seed on aromatase enzyme which depends on the concentrations of endogenous estrogens. The physiological effects of flax seed on reproductive system depend on the age of exposure and the dose of flax seed (33). The results of the present study can be compared with those obtained by other invistigators (15) demonstrated that treatment of diabetic rats with sage caused significant modulation in total sperm count, viability, motility and sperm morphology . Sage contains flavonoids phytoestrogens that make it very useful for women (34). Administration of salvia tablets to post menopausal women caused significant reduction in serum estradiol level compared with control group (35). Sage extract has aprominent effect so it is conceivable that it can improve male reproductive function (36) . Salvia rich with essential oil which has certain effect on fertility and this is why many parameters under study gave positive result for salvia effects (37). Other studies have shown that the normal function of leydig cells can be stimulated by antioxidants within salvia extract (16). The presence of vitamins $\mathrm{C}$ and $\mathrm{E}$ in the sage also plays an important role in the treatment of male infertility (17). The improving effects of salvia on male reproductive system may come from the effects of salvia component in particular vitamins $\mathrm{C}$ and $\mathrm{E}$, flavonoids and antioxidant (15). The presence of saponine, alkaloide in salvia extract caused asignificant increase in sperm activity in mice, which might be due to the stimulation of the growth of testes and enhancement of proliferation , maturation and differentiation of sperm by salvia extract as compared with the control group (18). 


\section{Acknowlegments:}

The authors acknolege the college of veterinary medicine for providing facilities and financial support to this study.

\section{Referance:}

1- Michael S. , Aaron M.B. and Ranjith R ., Asian J. Androl ., 18 (3) : 435 - 440 (2016).

2- Lund S.A., Murdoch J., Vankirk E.A., Murdoch W.J., Biol. Reprod . ,61 (2) : 388 - 392 (1999).

3- Schmidt A.J., Kreiy J. C. and Vedder H., J. Neu. Res ., 67 (40) : 544 - 550 (2002).

4-Barker M.E., Steroids . , 78 : 337 - 340 (2013) .

5-Per S., Horm. Behav .,4 (3) : 247 - 256 (1973).

6- Jurner K. J. , Morly M. , Atanassona N. , Swanton I. D. and Sharp R. M., J Endocrinol ., 164 : $225-238(2000)$.

7- Willem R. and Frank H.J., Reprod. Biol. Endocrinol. , 9 : 93 (2011).

8- Junker Walker U. and Nogues V., Exp. Toxicol. pathol ., 46 . 211 - 213 (1994).

9- Camil-Eugen V., Bianca - Eugenia O., Marcel P., Marius S., Amalia M., Paul B. and Amelia T. V., Farmacia ., 65 (3) : 336 -342 (2017).

10- Ivana L.J.N. , Ivana M.S., Ana D.T. and Ivan M.S., Advan. technol . , 6 (2) : 96 - 106 (2017) . 11- Thompson L.U., Rickard S.E. , Orcheson L.J. and Seidl M.M., Carci . ,17 : 1373 - 1776 (1996 )

12- Bygedman M. , Gottlieb C. , Swanborg K. and Swahn M.L., Role of prostaglandins in human reproduction : recent advances in : Advances in prostaglandin. Thomboxane and Leukotriene Research Vol 17 . Raven press . NewYork (1987).

13- Lanna B.N.S., Ludmila F.M., De F. C. , Ilma C. A., Gilson T.B. and Mauricio A.C., Pesq. Vet. Bras ., 37(6) : $650-656$ (1917).

14- Lu Y. and Foo L.Y., Polyphenolics of salvia - Areview phytochemistry ., 59 (2) : 117 - 140 (2002).

15- Al - Chalabi S.M.M., Shukri H.M. , Mahmood R.I. and Khalid L.B., J. Babylon Un./Pure Appl. Sci. , 24 (2) :390 - 399 (2016).

16- Perry N.M.S.L., Houghton P.J., Theoblad A.E., Jenner P. and Perry E.K., J. Pharmacol ., 52 : $89-95$ (2000).

17- Agrwal A., Prabakaran S.A. and Said T.M., J. Androl. , 26 (6) : 654 - 660 (2005).

18- Lima C.F. and Femandes - Ferreira M., Food Chem. Toxicol ., 45 (3) : 456 - 464(2007) 
19- Anurag B., Peter J. S. , Stephen J. M. , Vincenzo C. R. , Walid J. A. , John D. W. , Gail P. R. and George A. W., J. Endocrinol. , $207: 27$ - 34 (2010).

20- Ludmila F. M. D. C., Gilson T. B., Livia H. C. B. , Mauricio A. C., Food Chem. Toxicol ., 50 : $4092-4096$ (2012).

21- Amin A. and Hamza A. A., Life Sci .,77 : 266- 278 (2005).

22- Sakamoto J. and Hashimoto K., Arch . Toxicol., 59 :201 - 205 (1986).

23- Noakes D. E. and Parkinson T. J. Arthurs, Veterinary reproduction and obstetrics $8^{\mathrm{TH}}$ Ed . Gary C.W. , England. (2001).

24- Ratnasooriya W.D. , Ratnayake S.S.K. , Jayatunaga Y.N.A., Asian J. Androl. , 4(1) : 35 -41 (2002).

25- Hess R.A., Zhou Q. , Nie R. , Oliveira C. , Cho H. and Nakaia M., Reprod . Fertil. Devel .,13 (4) : $273-83(2001)$.

26- Finkelstein JS, Whitcomb RW, O'Dea LS, Longcope C, Schoenfeld DA and Crowley WF. , J. Clin. Endocrinol. and Met .,73:609-620 (1991).

27- Toppari J ., Environ . Health. Perspect ., 104 : 741 - 803 (1996).

28- Gunapala S. , Hanumanthappa K. , Hegganhalli N. K. , Ajay S. B. and Nuggehali R. M., Steroids .,63: $414-420$ (1998).

29- Adkins E.K., Boop J.J., Koutnik D.L. , Morris J.B. and Pniewski E.E. , Physio. Behav., 24 : 441 $-446(1980)$.

30- Bonsall R.W., Clancy A.N. and Michael R.P., Horm. Behav., 26 : 240 - 254 (1992).

31- Zumpe D. , Bonsall R. W. and Michael R.P., Horm. Behav., 27 : 200 - 215 (1993).

32- Brooks J.D. and Thompson L.U., J. Steroid. Biochem . Mol. Biol., 94 (5) : 461 - 467 (2005).

33- Tou J.C.L., Thesis for doctor . University of Toronto . Canada (1999).

34- Coxam V., J . Nutr., 89 (1) : 75 - 85 (2003) .

35- Rad S. K. , Forouhari A.S. ,Dehaghani A. S., Vafaei H. , Sayadi M. and Asadi M., Inter. J. Med. Res. Health Sci ., 5 (8) : 257 - 263 (2016).

36- Lindi L. , Haolin C., Michael A., Trush M. D. and Barry R., J. Androl ., 22 : 32-37 (2005).

37- Aron P. M. and Kennedy J. A., Mol. Nutr . Food Res., 52 : 79 - 104 (2008). 